\title{
Propagating Figured Wood in Black Walnut
}

\author{
James R. McKenna1, Wayne A. Geyer ${ }^{2}$, Keith E. Woeste', Daniel L. Cassens ${ }^{3}$ \\ ${ }^{1}$ USDA-Forest Service, Northern Research Station, West Lafayette, USA \\ ${ }^{2}$ Kansas State University, Manhattan, KS, USA \\ ${ }^{3}$ Purdue University, West Lafayette IN, USA \\ Email: jamesmckenna@fs.fed.us, wgeyer@ksu.edu
}

Received 6 April 2015; accepted 12 June 2015; published 15 June 2015

Copyright (C) 2015 by authors and Scientific Research Publishing Inc.

This work is licensed under the Creative Commons Attribution International License (CC BY). http://creativecommons.org/licenses/by/4.0/

\section{(c) (i) Open Access}

\section{Abstract}

Figured black walnut lumber is a specialty wood product that commands a high price for manufacturing fine furniture and interior paneling. Two common figured grain patterns occur in walnut; they are known as "fiddle-back" or "curly" grain, depending on the number of horizontal lines visible in the grain of the finished wood. The occurrence of figured walnut in nature is rare and unpredictable. Trees that have consistent figured patterns throughout the log are of exceptional value. Conversely, trees with partial or spotty figured patterns are considered defective and are reduced in value. Conventional breeding of seedlings, or cloning figured trees by grafting, are possible methods to propagate figured wood in walnut. The value of such material, however, will depend on figure being expressed predictably. For breeding to succeed, the trait of interest must be genetic and heritable. For clonal propagation to be effective, the trait must be reproduced true-totype. In this study, we evaluate the grain pattern of both grafted and seedling walnut from several highly figured wild selections. Logs from grafted trees of three clones propagated in the 1970s in Kansas were evaluated. Only one log from one clone showed some figure in its lumber. Ten-yearold seedlings from the figured walnut clone "Lamb" were grown and cut in Indiana and evaluated for figured grain, and none showed any sign of figured grain developing. Our conclusion is that figured grain in black walnut does not propagate true-to-type through grafting or by growing open-pollinated seed. Although evidence of some genetic control of figure was found, environmental and other factors appear to play a greater role.

\section{Keywords}

Juglans nigra, Figured Wood, Forestry Breeding, True-to-Type, Grafting, Clonal Forestry

\section{Introduction}

Black walnut (Juglans nigra L.) is an important timber species valued for its workability, luster, and chocolate 
brown-colored heartwood. Black walnut historically has been one of the most valuable hardwood species in the Central Hardwood region of the United States for veneer and furniture industries (Geyer \& Rink, 1998; Cassens, 2004; Victory et al., 2004). Figured walnut is characterized by horizontal or diagonal lines in the grain pattern of finished wood, making it visually striking because it gives two-dimensional wood surfaces a three-dimensional appearance. Figure is rare in most tree species and occurs in many forms known in the wood products industry; when it does occur, and when it is consistent with a regular pattern throughout the log, the wood is highly prized (Beals \& Davis, 1977). Three general types of figured patterns in wood are recognized: normal figure, such as ray flecks, cathedral patterns, or interlocked grain; pigment figure, resulting from color variation within wood; and specific figure, which results from non-vertical alignment of longitudinal fibers resulting in visible stripes or corrugations appearing nearly perpendicular to the axis of the stem (Beals \& Davis, 1977; Panshin et al., 1980). "Fiddleback" and "curly" figure, distinguished by the width between corrugations (Figure 1), are the two types of specific figure that occur in walnut (Beals \& Davis, 1977; Panshin et al., 1980).

Tension wood forms at the buttress zone of the bole and at the base of large side branches and functions to increase the strength of tree trunks and limbs, often produces fiddleback and curly figured grain patterns (Panshin et al., 1980). In contrast, specific figure, occurs between whorls of branches and its function is unknown. Often only portions of the bole have figure. In most cases, figured grain does not begin immediately in a tree's life but starts to develop after several years. Because most timber species worldwide produce some degree of figured wood, Beals and Davis (1977) have suggested that the trait may result from an aberration of cambial function and radial growth and, as such, does not have any particular adaptive value for trees.

Along with black walnut, other notable North American fine hardwood species that produce fiddleback or curly figured grain include sugar maple (Acer saccharum), northern red oak (Quercus rubra), black cherry (Prunus serotina), and white ash (Fraxinus americana). Certain soils, geographical locations, and site conditions have been associated with figure. Beal and Davis (1977) note that figured wood of several species is produced to a far greater extent in the Pacific Northwest than in other regions. Open-grown trees with short boles and wide branching may have increased figure formation; a considerable number of figured logs are harvested from grafted trees grown in orchards, particularly of Persian walnut (J. regia). Birdseye sugar maple, a specific figure of dimpled patterns in the wood, is more common in the northern portions of its natural range. Curly figure is common in yellow birch (Betula alleghaniensis) in the northern US and Canada and is also present in a few European birch species (Heikinheimo, 1951; Beals \& Davis, 1977). Fiddleback figure occurs in sycamore maple (Acer pseudoplatanus) in parts of Europe, and in bigleaf maple (A. macrophyllum) in Oregon and Washington States, USA. Investigating factors that cause figured grain to develop is challenging because few visible external signs on the bark of standing trees reliably indicate figure, and figure can take from 5 to 20 years to express (Beals \& Davis, 1973; Beals \& Davis, 1977).
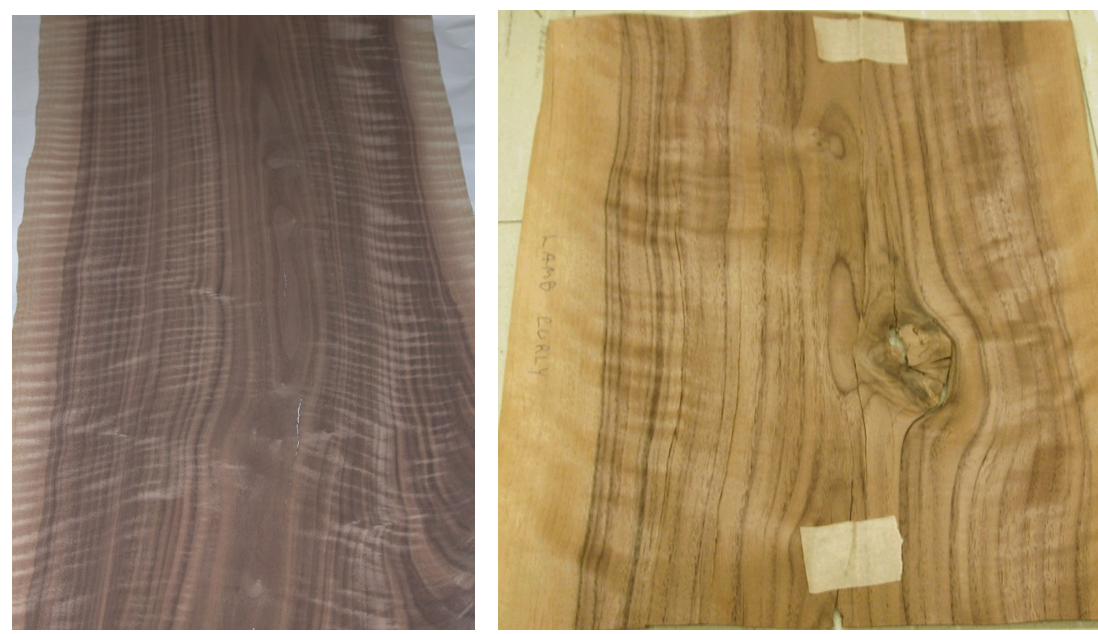

Figure 1. Examples of figured grain types in black walnut. A fiddleback sample from a wild tree in Iowa exemplifies the type of commercially valuable figured grain black walnut clones have been selected for and that are desired to reproduce (left). A curly sample from a relatively young grafted 'Lamb’ tree from Kentucky (right). 
Figure has been reproduced by vegetative propagation in some cases, suggesting that genetic control exists for some species. European birch (B. verrucosa, B. pendula, and B. pendula var. Carelica) produce unique types of figured grain termed "Masur" or "flamy" figure, which have been propagated as both grafted trees and seedling progeny (Heikinheimo, 1940, 1951; Scholz, 1962). A European hybrid aspen known as Populus $\times$ canescens, a natural complex hybrid between two European species, P. alba and P. tremula (Rajora \& Dancik, 1992), has produced individual trees that have figured grain reproducible through cloning (Grober, 1946; Fan, 2010). A P. $\times$ canescens clone, “Grober”, recently has been shown to reproduce figured wood consistently by grafting or by rooting cuttings, much like Masur birch. Grafting and F1 progeny tests have shown figure in "Grober” expresses true-to-type and is heritable (Fan et al., 2013). The "Grober” aspen, however, has a unique type of figured grain described as "Scattered Moiré,” which differs from fiddleback or curly figure in walnut.

In the early 20th century, George Lamb, a veneer buyer of figured walnut and mahogany, found a highly figured curly walnut harvested in January 1926 near the town of Ada, Michigan (Lamb, 1941; Wilkinson, 1948). Lamb obtained scion wood, and distributed it to nurserymen and members of the Northern Nut Growers Association (NNGA) to graft and preserve, and suggested that figured walnut could be propagated asexually or sexually (Lamb, 1941). Lamb stated that the veneer from this tree was valued at \$9094 in 1926 US dollars, which would be about \$100,000 today. Soon after, the tree became known as “Lamb’s Curly”. The staggering value of this tree, and George Lamb's association with NNGA members eager to grow valuable figured walnut wood (Lamb, 1941; Wilkinson, 1948), began the research that continues today.

If breeding of figured wood is to succeed, the trait must have a genetic basis and be heritable, so that seedlings will express figure in a predictable proportion. To examine the heritability of phenotypic traits in general and figured wood in black walnut in particular, one needs to evaluate both figured $\times$ straight grain F1 and F2 progeny (Allard, 1960). To evaluate walnut progeny for figured grain, seedlings need to be grown for several decades to allow their figured grain to express, and trees must be coppiced so stem segments can be split to evaluate grain patterns. If heritability is low, another round of breeding and selection would be required to increase the percentage of figured seedlings and to reduce variation among seedlings. Environmental and cultural factors that affect expression of figured grain also need to be determined and accommodated if breeding is to succeed.

To avoid intrinsic seedling variation, many tree varieties are propagated clonally as grafted plants (Hartmann et al., 2010). Just as seedlings are tested and developed to breed true, grafted cultivars must be tested to determine if the trait(s) of interest will propagate true-to-type. A trait is said to come true-to-type when each asexually derived plant expresses the same trait as its progenitor clone (Hartmann et al., 2010). Attempts to graft the "Lamb” figured walnut have been made in the past but with very few and mixed results (Walters, 1951; MacDaniels, 1953; Stoke, 1966; Beals \& Davis, 1977). Although Wilkinson (1948) stated that he believed every grafted "Lamb" would produce curly figure, he provided only one small sample from one single 12-year-old grafted tree that showed some figure (Walters, 1951).

Since the discovery of the curly "Lamb" walnut, tree improvement specialists around the Central Hardwood region of the US have collected and grown trees from scion wood originating from other highly figured walnut trees. In the 1970s, Dr. Loy Shreve of the Kansas Forest Service obtained scion wood from eight highly figured walnut trees. More recently, the Hardwood Tree Improvement and Regeneration Center (HTIRC) of the USDAForest Service, Northern Research Station, established clone banks and seed orchards of these and 16 other figured walnut clones as part of a breeding program aimed to develop, improve, and regionally adapt fine hardwood planting stock for the Central Hardwood region. Here we present the results from milling logs of three grafted figured walnut clones planted more than 30 years ago in a seed orchard in Kansas to determine if figured grain can be propagated true-to-type through grafting. We also examine 10-year-old open-pollinated "Lamb” seedlings that were grown in a black walnut plantation in Indiana for figured grain.

\section{Methods}

Trees were grafted onto seedling rootstocks and grown in a forestry seed orchard at the Milford Reservoir, Junction City, Kansas, established by the Kansas Forest Service in the 1970s. The ortets (original wild trees) were selected because they had valuable figure reported by sawmills, and the location of each tree was known to allow for the collection of viable scion wood. Ramets (grafted trees) of three figured clones, “Osage Co. \#1” (ortet from Kansas), "Harold Davis \#2” (ortet from Kansas), and "Pfeister” (ortet from Nebraska), were selected among eight other figured clones in the orchard because there were at least five trees with logs of sufficient size 
to harvest and mill into lumber. Once cut, the end of each log was color-coded with paint and replicate logs were identified with black stripes to indicate the clone and replicate tree throughout the milling and evaluation process.

To ensure that the correct clones were sampled, DNA genotypes were determined. Leaves were collected in 2005 from the Kansas and Indiana orchards, and DNA was extracted to verify genotypes using three DNA microsatellite simple sequence repeat (SSR) markers (Woeste et al., 2002). Scion wood from the Milford Reservoir orchard in Kansas was re-propagated by the University of Nebraska and the Nebraska Nut Growers Association (NeNGA) in the 1980s in Lincoln, Nebraska, and later, the HTIRC re-propagated these clones from Nebraska in 2000 to establish new clone banks and breeding orchards in Indiana.

Cross-sections of each log were collected at the time of harvest, dried and sanded, and growth rings were counted to age each tree and determine the percentage of heartwood and sapwood. Logs were milled into fourquarter lumber on a portable sawmill, stacked, and air-dried for two months, then surface-planed, and boards were visually inspected for figured grain. Ten half-sibling open-pollinated seedlings from a grafted "Lamb" walnut were harvested after 10 years of growth in a black walnut progeny test at the Forestry and Natural Resources Farm, Purdue University, West Lafayette, Indiana, in 2010. The basal 18 inches of each trunk was split with a hatchet (split-test) to determine the presence or absence of figured wood (Beals \& Davis, 1977).

\section{Results}

Genotyping of the grafted trees from the Kansas seed orchard showed that clones were consistent with one another with the exception of one "Pfeister" tree that appeared to be rootstock (Table 1). SSR genotypes matched clones re-propagated in Nebraska and Indiana with the exception of one clone. An error occurred in Indiana in which "Osage Co. \#1" was mixed up with another clone. All logs were statistically similar for age, sapwood rings, DBH, log length, and lumber volume; "Osage Co. \#1" had a significantly lower percentage of heartwood compared with the other two clones (Table 2). Figured grain was found in several boards of one "Harold Davis \#2" log, but the amount and consistency of figured grain was small (Figure 2), and with only one positive figured sample, no statistical analysis was possible.

\section{Discussion}

How often commercially valuable figured grain occurs in natural stands of walnut is difficult to estimate. Discussions with wood products representatives indicate that only $1 / 500$ to $1 / 1000$ walnut trees may exhibit valuable figure. The fact that we observed some figure in one of nine logs may indicate a real genetic component for figure in walnut, but the expressivity and penetrance of the trait is low. The little figure expressed in our study suggests that environmental $(G \times E)$ factors, which we do not yet understand, are critical for figure to develop consistently throughout a walnut log.

Beals and Davis (1977) note that open-grown conditions have been associated with developing figured grain, and because our trees were grown in a widely spaced seed orchard, we had hoped that this environmental factor would be conducive to the development of figured grain. Prior to the present study, we harvested and milled two grafted "Lamb" trees in Indiana (data not shown). One tree had no figured grain at all, and the other tree had a little figure in a portion of the bole much like the "Harold Davis\#2" log in Figure 2. The veneer sample from a grafted "Lamb" in Figure 1 shows curly figure, but the commercial value of this sample is questionable. Decades ago, a sample with better curly figure from a single grafted 12-year-old "Lamb" tree was brought to the NNGA annual meeting and photographed (Walters, 1951; MacDaniels, 1953). These few examples and the figure we observed in the present study are the only documented cases of figured walnut having been propagated by grafting.

MacDaniels (1953) expressed concern about the misidentification of a grafted "Lamb" walnut cut at Cornell University in Ithaca, NY, and misidentification of genotypes of trees certainly occurs (Coggeshall \& Woeste, 2010). Through DNA genotyping, we were confident that we had identified the correct clones and trees to the best of our ability. DNA genotyping showed that all ramets of the three clones in the Kansas seed orchard matched each other, with the exception of one "Pfeister" tree (Table 1), which was likely rootstock. All "Harold Davis \#2" ramets and all "Pfeister" ramets matched each other in Kansas and those more recently grafted in Indiana. There was a mistake grafting "Osage County \#1" in Indiana, where only one of five grafted ramets matched the Kansas ramets. 
Table 1. Genotypes of grafted trees of three clones propagated by the Kansas State Forest Service at the Milford Reservoir, Junction City, Kansas, and newly grafted trees propagated by the HTIRC at two locations in Indiana based on three DNA microsatellite simple-sequence-repeat (SSR) markers. Values represent the base-pair sizes of each allele.

\begin{tabular}{|c|c|c|c|c|c|c|c|c|c|c|}
\hline \multirow[b]{3}{*}{ Lab \# } & \multirow[b]{3}{*}{ Clone } & \multirow[b]{3}{*}{$\mathrm{ST}$} & \multicolumn{7}{|c|}{ SSR Markers } & \multirow[b]{3}{*}{ Sum $^{\mathrm{E}}$} \\
\hline & & & \multirow{2}{*}{$\begin{array}{l}\text { Orchard } \\
\text { Location }\end{array}$} & \multicolumn{2}{|c|}{ WAG 82} & \multicolumn{2}{|c|}{ WAG 89} & \multicolumn{2}{|c|}{ WAG 72} & \\
\hline & & & & Allele 1 & Allele 2 & Allele 1 & Allele 2 & Allele 1 & Allele 2 & \\
\hline 5 & Osage Co. \#1 & KS & RD-T1 & 180 & 186 & 205 & 209 & 146 & 148 & 1074 \\
\hline 6 & Osage Co. \#1 & KS & RD-T29 & 180 & 186 & 205 & 209 & 146 & 148 & 1074 \\
\hline 7 & Osage Co. \#1 & KS & RB-T5 & 180 & 186 & 205 & 209 & 146 & 148 & 1074 \\
\hline 8 & Osage Co. \#1 & KS & RB-T10 & 180 & 186 & 205 & 209 & 146 & 148 & 1074 \\
\hline 9 & Osage Co. \#1 & $\mathrm{KS}$ & RD-T19 & 180 & 186 & 205 & 209 & 146 & 148 & 1074 \\
\hline 10 & Osage Co. \#1 & KS & RK-T32 & 180 & 186 & 205 & 209 & 146 & 148 & 1074 \\
\hline 11 & Osage Co. $\# 1^{\mathrm{A}}$ & IN & R8-T2 & 166 & 200 & 197 & 197 & 146 & 148 & 1054 \\
\hline 12 & Osage Co. $\# 1^{\mathrm{B}}$ & IN & R15-T2 & 180 & 186 & 205 & 209 & 146 & 148 & 1074 \\
\hline 13 & Osage Co. $\# 1^{\mathrm{C}}$ & IN & R1-T66 & 166 & 200 & 197 & 197 & 146 & 148 & 1054 \\
\hline 14 & Osage Co. \#1 & IN & R2-T68 & 166 & 200 & 197 & 197 & 146 & 148 & 1054 \\
\hline 15 & Osage Co. \#1 & IN & R4-T64 & 166 & 200 & 197 & 197 & 146 & 148 & 1054 \\
\hline 16 & Harold Davis \#2 & KS & RC-T14 & 190 & 192 & 187 & 195 & 150 & 152 & 1066 \\
\hline 17 & Harold Davis \#2 & KS & RI-T27 & 190 & 192 & 187 & 195 & 150 & 152 & 1066 \\
\hline 18 & Harold Davis \#2 & KS & RB-T46 & 190 & 192 & 187 & 195 & 150 & 152 & 1066 \\
\hline 19 & Harold Davis \#2 & KS & RE-T22 & 190 & 192 & 187 & 195 & 150 & 152 & 1066 \\
\hline 20 & Harold Davis \#2 & KS & RI-T31 & 190 & 192 & 187 & 195 & 150 & 152 & 1066 \\
\hline 21 & Harold Davis \#2 & IN & R4-T4 & 190 & 192 & 187 & 195 & 150 & 152 & 1066 \\
\hline 22 & Harold Davis \#2 & IN & R2-T69 & 190 & 192 & 187 & 195 & 150 & 152 & 1066 \\
\hline 23 & Harold Davis \#2 & IN & R3-T79 & 190 & 192 & 187 & 195 & 150 & 152 & 1066 \\
\hline 24 & Harold Davis \#2 & IN & R4-T65 & 190 & 192 & 187 & 195 & 150 & 152 & 1066 \\
\hline 25 & Harold Davis \#2 & IN & R5-T67 & 190 & 192 & 187 & 195 & 150 & 152 & 1066 \\
\hline 26 & Pfeister & KS & RD-T9 & 156 & 218 & 207 & 215 & 146 & 148 & 1090 \\
\hline 27 & Pfeister & KS & RA-T10 & 156 & 218 & 207 & 215 & 146 & 148 & 1090 \\
\hline 28 & Pfeister & KS & RB-T17 & 156 & 218 & 207 & 215 & 146 & 148 & 1090 \\
\hline 29 & Pfeister ${ }^{\mathrm{D}}$ & KS & RC-T43 & 164 & 166 & 207 & 207 & 148 & 148 & 1040 \\
\hline 30 & Pfeister & KS & RI-T32 & 156 & 218 & 207 & 215 & 146 & 148 & 1090 \\
\hline 31 & Pfeister & IN & R8-T7 & 156 & 218 & 207 & 215 & 146 & 148 & 1090 \\
\hline 32 & Pfeister & IN & R1-T54 & 156 & 218 & 207 & 215 & 146 & 148 & 1090 \\
\hline 33 & Pfeister & IN & R2-T67 & 156 & 218 & 207 & 215 & 146 & 148 & 1090 \\
\hline 34 & Pfeister & IN & R3-T74 & 156 & 218 & 207 & 215 & 146 & 148 & 1090 \\
\hline 35 & Pfeister & IN & R4-T70 & 156 & 218 & 207 & 215 & 146 & 148 & 1090 \\
\hline 36 & Pfeister & IN & R5-T65 & 156 & 218 & 207 & 215 & - & - & - \\
\hline
\end{tabular}

${ }_{\mathrm{A}}^{\mathrm{A}}$ Incorrect clone at Purdue, Martell Forest Figured Seed Orchard, derived from scionwood from the Southeast Purdue Agricultural Center (SEPAC)

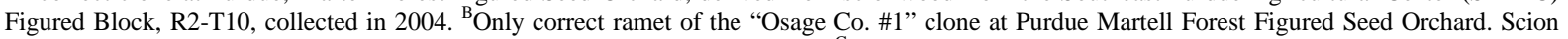
wood for tree came from the SEPAC Figured Block, R1-T7, collected in 2004. ' Incorrect clone at Purdue, Martell Forest Juglans Germplasm Block, derived from scionwood from the SEPAC Figured Block, R2-T10, collected in 2004. ${ }^{\mathrm{D}}$ Rootstock that grew in place of the scion. ${ }^{\mathrm{E}}$ Arbitrary sum of marker sizes to quickly check accuracy of clones. 
Table 2. Growth, lumber, and wood grain characteristics of the three clones harvested from the Kansas State Forest Service Milford Reservoir walnut seed orchard in 2006.

\begin{tabular}{|c|c|c|c|c|c|c|c|c|}
\hline $\log$ & Clone & $\mathrm{Age}^{\mathrm{A}}$ & $\begin{array}{l}\text { Sapwood } \\
\text { Rings }\end{array}$ & $\begin{array}{c}\mathrm{DBH} \\
\text { (inches) }\end{array}$ & $\begin{array}{l}\text { Log } \\
\text { Length } \\
\text { (ft) }\end{array}$ & $\begin{array}{l}\text { Volume } \\
\text { (bdf) }^{\mathrm{B}}\end{array}$ & Heartwood \% ${ }^{\mathrm{C}}$ & $\begin{array}{c}\text { Figured } \\
\text { Grain }^{\mathrm{E}}\end{array}$ \\
\hline 1 & Osage Co. \#1 & 26 & 11 & 11.5 & 9 & 32 & 56 & No \\
\hline 2 & Osage Co. \#1 & 30 & 12 & 15.4 & 7 & 57 & 63 & No \\
\hline 3 & Osage Co. \#1 & 27 & 13 & 10.5 & 8 & 27 & 45 & No \\
\hline Avg. & & 28 & 12 & 12.5 & & 37 & $55^{* \mathrm{D}}$ & \\
\hline 1 & Harold Davis \#2 & 25 & 8 & 9.5 & 9 & 17 & 69 & Yes $^{\mathrm{F}}$ \\
\hline 2 & Harold Davis \#2 & 29 & 12 & 12.3 & 8 & 34 & 83 & No \\
\hline 3 & Harold Davis \#2 & 24 & 10 & 9.6 & 7 & 14 & 79 & No \\
\hline Avg. & & 26 & 10 & 10.5 & & 22 & $77^{*}$ & \\
\hline 1 & Pfeister & 28 & 10 & 14.8 & 6 & 44 & 70 & No \\
\hline 2 & Pfeister & 33 & 14 & 14.4 & 5 & 34 & 73 & No \\
\hline 3 & Pfeister & 29 & 11 & 9.6 & 8 & 16 & 71 & No \\
\hline Avg. & & 30 & 12 & 12.9 & & 31 & $72^{*}$ & \\
\hline
\end{tabular}

${ }^{\mathrm{A}}$ Total growth rings from cross-sections at 3 to 5 inches above graft union. ${ }^{\mathrm{B}}$ (bdf) is volume in board feet by the Doyle Log Rule. ${ }^{\mathrm{C}} \mathrm{Heartwood}$ content was calculated by dividing heartwood diameter by total diameter $\times 100$. ${ }^{\mathrm{D}}$ Differences in heartwood content were significant by one-way ANOVA at $P \leq 0.02$. ${ }^{\mathrm{E}}$ Visual observation of dried and planed lumber for presence or absence of figured grain. ${ }^{\mathrm{F}}$ Some figure was observed on this log of "Harold Davis \#2” (see Figure 2).

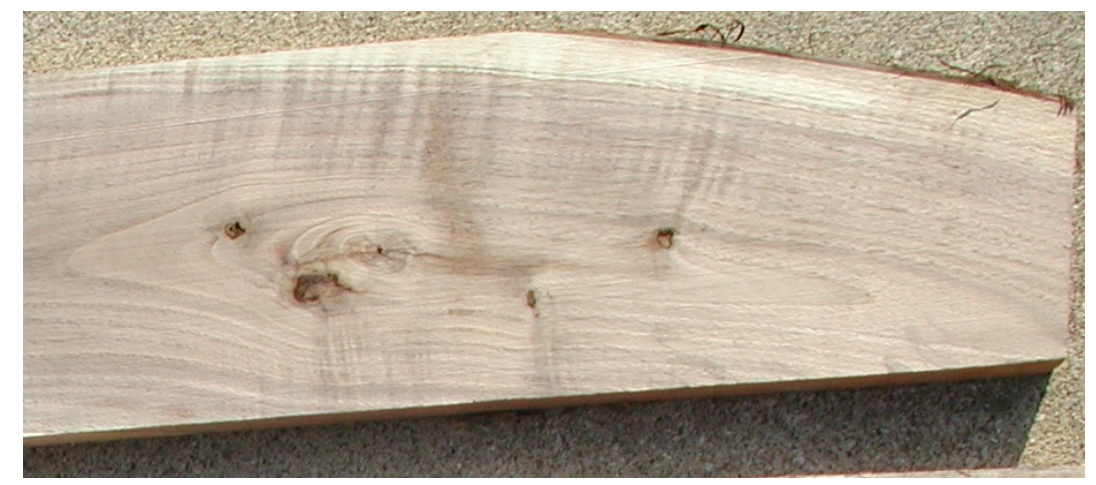

Figure 2. Close-up of the figure found in one log of "Harold Davis \#2”.

In the 1930s, a member of NNGA, Mr. John Rink, planted 300 grafted "Lamb” trees in Pennsylvania (Stoke, 1966; Ken Dooley, personal comm.). Since that time, through scion wood exchanges among NNGA members, many others have grafted "Lamb". If anyone had successfully propagated a plantation with a considerable number of valuable highly figured black walnut trees, it is plausible that such information would have been publicized and even commercialized by now. The fact that no one to date has reported or noted any substantial figured lumber derived from previously planted trees and the present study's limited expression of figured grain in walnut lumber strongly suggest that commercially valuable figured walnut planting stock remains to be developed.

One explanation for the low expression of figure in grafted trees could have to do with alterations in the physiology of grafted trees. The root system from the ortet may be important in the hormone balance responsible for figured grain formation in the stem. The plant hormone auxin, synthesized in shoot tips, affects the orientation of microfibrils of cell walls and cell expansion (Taiz \& Zeigler, 1991). Cytokinin, a second plant hormone involved in cell division and differentiation, is synthesized in root tips and travels upward to the shoot system. Changes in the ratio of auxin: cytokinin can affect plant development processes (Davies, 1987; Hartmann et al., 2010). A distinct auxin and cytokinin ratio could be necessary for figure to develop, and grafting could disrupt 
that ratio and lower the expression of figured wood development.

Breeding seedlings may avoid physiological differences between root and shoot systems and produce more widely available planting stock; however, the type of genes and genetic mechanism of figure in walnut remains to be determined. Unlike grafted walnut, seedlings have not been reported to produce figure. Walnut tends to outcross at least $90 \%$ of the time, and although selfed progeny occur and grow, they have been found to suffer slower growth and reduced survival (Rink et al., 1994; Robichaud, 2007). Beal and Davis (1977) note that figured trees often have slow growth and reduced vigor; thus, figure in walnut may be controlled by recessive genes. Our results with open-pollinated seedlings support this hypothesis. Indeed, if the genes for figure in walnut are recessive, only selfed families and figured $\mathrm{x}$ figured crosses would be expected to show figured grain.

\section{Conclusion}

Evaluation of lumber from three grafted figured walnut clones grown for nearly 30 years in a seed orchard did not propagate commercially valuable figured grain; only one of nine logs showed a small amount of figure. The fact that some figured grain was expressed indicates that the trait may have some genetic component in walnut, but the genetic mechanism is not known. Plantings of seedlings from isolated seed orchards containing these figured clones and others have been established in Indiana to investigate the role that root systems, figured $\times$ figured crosses, and selfing have on figured grain expression. In the meantime, landowners, foresters, and nurseries are cautioned that figured black walnut planting stock has not been demonstrated to propagate commercially valuable figured walnut lumber.

\section{Acknowledgements}

The USDA-Forest Service Northern Research Station and the Kansas State Forest Service and the Department of Forestry \& Natural resources at Purdue University provided staff and support to conduct this study. Brian Beheler, Jewel Yeager, Daniel Werner, John Canaday, Charles Michler, John Seifert, Rodney Robichaud, and others at Kansas State University helped identify, collect, and process material. Ken Dooley of the Indiana Nut Growers Association provided NNGA communications. Walter F. Beineke, the late Cyril Bish of the Nebraska Nut Growers Association, Archie and Brian Sparks from the Iowa Nut Growers Association, Boynton Merrill and Paul Christofferson of the Black Walnut council provided figured walnut samples. The Fred M. van Eck Foundation of the HTIRC at Purdue University provided funding. Mention of a trademark, proprietary product, or vendor does not constitute a guarantee or warranty of the product by the US Department of Agriculture and does not imply its approval to the exclusion of other products or vendors that also may be suitable. This is contribution number 15-043-J from the Kansas Agricultural Experiment Station.

\section{References}

Allard, R. W. (1960). Principles of Plant Breeding. New York: John Wiley \& Sons, 485 pp.

Beals, H. O., \& Davis, T .C. (1977). Figure in Wood-An Illustrated Review. Auburn Alabama: Auburn University. Alabama Agricultural Experiment Station Bulletin \#486, 5 pp.

Beals, H. O., \& Davis, T. C. (1973). An Annotated Bibliography of Figure in Wood. Auburn Alabama: Auburn University. Alabama Agricultural Experiment Station Circular 205, 18 pp.

Cassens, D. L. (2004). Factors Affecting the Quality of Hardwood Logs for Face Veneer. FNR-239. West Lafayette, IN: Purdue University, 12 p.

Coggeshall, M. V., \& Woeste, K. E. (2010). Microsatellite and Phenological Descriptors Identify Eastern Black Walnut Cultivars in Missouri, USA. In N. V. Bassil, \& R. Martin (Eds.), Proc. on Molecular Markers in Horticulture. Acta Hort. No. 859, 93-98.

Davies, P. J. (1987). Plant Hormones and Their Role in Plant Growth and Development. Leiden, Boston, MA: Martinus Nijhoff Publishers, 681 pp. http://dx.doi.org/10.1007/978-94-009-3585-3

Fan, Y. (2010). Phenotypic and Genetic Characterization of a Hybrid Aspen (Populus $\times$ canescens). Ph.D. Dissertation, West Lafayette, IN: Purdue University, 189 pp.

Fan, Y., Rupert, K., Wiedenhoeft, A. C., Woeste, K., Lexer, C., \& Meilan, R. (2013). Figured Grain in Aspen Is Heritable and Not Affected by Graft-Transmissible Signals. Trees, 27, 973-983. http://dx.doi.org/10.1007/s00468-013-0849-1

Geyer, W. A., \& Rink, G. (1998). Interaction Effects of Seed Source, Culture, and Pest Management on Growth of Juglans 
nigra in Plantations. Silvae Genetica, 47, 51-58.

Grober, S. (1946). Science Shows the Way. Chemurgic Digest, 5, 152.

Hartmann, H. T., Kester, D. E., \& Davies Jr., F. T. (2010). Plant Propagation: Principles and Practices (8th ed., 915 p). Upper Saddle River, NJ: Prentice Hall.

Heikinheimo, O. (1940). Om Odling av Masurbjörk (On Experiments with Masur-Birch). Skogen, 27, 165-167. Text in Swedish. 7 Photos (Duke University Library)

Heikinheimo, O. (1951). Kokemuksia Visakoivun Kasvatukesta (Experiences in the Growing of Curly Birch). Communicationes Instituti Forestalis Fenniae, 39, 4-26. Text in Finnish. English Summary. 9 Figures, 18 References. (Duke University Library) 27, 165-167. Text in Swedish. 7 Photos (Duke University Library)

Lamb, G. N. (1941). Figure in Wood. Northern Nut Growers Assoc. Ann. Rept, 31, 28-33.

MacDaniels, L. H. (1953). Some Aspects of the Problem of Producing Curly-Grained Walnut. 44th Annual Report of the Northern Nut Growers Association, 72-79.

Panshin, A. J., \& de Zeeuw, C. (1980). Textbook of Wood Technology (722 p). New York: McGraw-Hill Book Company.

Rajora, O. P., \& Dancik, B. P. (1992). Genetic Characterization and Relationships of Populus alba, P. tremula, and P. canescens, and Their Clones. Theoretical and Applied Genetics, 84, 291-298.

Rink, G., Zhang, G., Jinghua, Z., Kung, F. H., \& Carroll, E. R. (1994). Mating Parameters in Juglans nigra L. Seed Orchards Are Similar to Natural Population Estimates. Silvae Genetica, 43, 261-263.

Robichaud, R. L. (2007). Pollen Gene Dispersal in Black Walnut across a Heterogeneous Landscape in Central Indiana. Ph.D. Dissertation, West Lafayette, IN: Purdue University.

Scholz, E. (1962). Erhöhung und qualitative Verbesserung des inländischen Aufkommens an Birkenfurnierholz durch Anwendung wissenschatlicher Erkenntnisse (Increasing and Improving Home Supplies of Birch Veneer on Scientific Bases). Sozialistiche Forstwirtschaft, 12, 364-369. Text in German. 14 Photos. 6 References. Forestry Abstracts Volume 24 No. 4296. (Purdue University Library)

Stoke, H. F. (1966). Lamb Walnut. The Nutshell. Northern Nut Growers Association, XLII, 3-5.

Taiz, L., \& Zeiger, E. (1991). Plant Physiology (559 p). Boston: Benjamin/Cummings Publishing Co. Inc.

Victory, E., Woeste, K., \& Rhodes, O. (2004). History of Black Walnut Genetics Research in North America. In Black Walnut in a New Century: Proceedings of the 6th Walnut Council Research Symposium Station (188 p). St. Paul, MN: U.S.D.A.

Walters, C. S. (1951). Figured Walnut Propagated by Grafting. Journal of Forestry, 49, 917.

Wilkinson, J. F. (1948). The Grafted Curly Walnut as a Timber Tree. Northern Nut Growers Association Annual Proceedings, 39, 139-142.

Woeste, K., Burns, R., Rhodes, O. E., \& Michler, C. (2002). Thirty Polymorphic Nuclearmicrosatellite Loci from Black Walnut. Journal of Heredity, 93, 58-60. http://dx.doi.org/10.1093/jhered/93.1.58 